\title{
Organ and tissue donation in the intensive care unit: collaborative endeavours
}

Graeme Rocker MHSc DM FRCP FRCPC

I N November 2002 a Canadian Medical Association Journal commentary ${ }^{1}$ drew attention to several organ and tissue donation-related issues in the critical care unit. In this summary of the Canadian Critical Care Society (CCCS) process that led to a position paper on organ and tissue donation, [available from the CCCS web-site (www.canadiancriticalcare.org)], the CCCS called for collaboration with other groups in a "spirit of mutual understanding and respect." It is heartening to see such collaborations taking shape. One initiative has been the forging of stronger links between the CCCS and the Canadian Journal of Anesthesia. This has resulted in the publication, beginning with this edition, of a series of articles by CCCS members who participated in our organ and tissue donation working group deliberations. In this edition of the Canadian Journal of Anesthesia, an article entitled "Brain Death: resolving inconsistencies in the ethical declaration of death" reflects Doig's and Burgess' personal and professional assessment of the development of the concepts of brain death from the early deliberations of a 1968 committee at Harvard Medical School up to the present. ${ }^{2}$

There were many reasons to create a working group of the CCCS to address organ and tissue donation, not the least of which was our own perception that as critical care physicians, we were not sufficiently involved in processes to improve or optimize organ and tissue donation rates. We remain the physicians most likely to be involved in the care of potential organ donors in the intensive care unit (ICU). In addition, ICU physicians are the clinicians most likely to be affected by any strategies introduced by agencies charged with seeking to improve Canada's organ and tissue donation rates.

Some of these potential strategies include changes to legislation to allow information about potential organ donors to be forwarded to third parties that would otherwise have remained confidential. Other strategies under discussion include consideration of organ donation from patients declared dead by cardiovascular criteria (rather than by conventional brain death criteria). These patients would become nonheart beating donors. ${ }^{3}$ This approach is often used in the Netherlands and in some US centres. To address these and other issues, we brought together five nonphysicians and eight ICU specialists to comprise our working group. The non-physicians were: bioethicists (Kerry Bowman PhD, University of Toronto, Alister Browne PhD, Langara College, British Columbia) a health law expert (Jocelyn Downie SJD, Dalhousie University) and two members of the public representing the family of an organ donor (Diane Craig, Ontario) and the family of an organ recipient (Lois Scott, New Brunswick). The eight ICU physicians (Peter Dodek, Vancouver; Paul Boiteau, Chip Doig, Calgary; Catherine Farrell, Montreal; Giuseppe Pagliarello, Ottawa; Graeme Rocker, Halifax (Chair), Sam Shemie, Toronto and Gordon Wood, Victoria represented six provinces with both tertiary centre, community, adult and pediatric interests.

Once we had crafted our first draft of the position paper much iteration followed in course of reflection and building of consensus. The bound version of the executive summary was distributed in August 2002. In this position paper we called, for example, for a moratorium on non-heart beating donor programs in Canada to allow for wider discussion and debate of the ethical issues that arise in such a context. The CCCS has attracted some comments on its conservative stance on this issue (which we expected), but we stand by our call for wider discussion. For this reason we are delighted that the Canadian Journal of Anesthesia has agreed to publish an article in a later issue on ethical

\footnotetext{
Department of Medicine (Respirology), Dalhousie University, Halifax, Nova Scotia, Canada.

Address correspondence to: Dr. Graeme Rocker, President, Canadian Critical Care Society, 4457 Halifax Infirmary, 1796 Summer Street, Halifax, Nova Scotia B3H 3A7, Canada. Phone: 902-473-6611; Fax: 902-473-6202; E-mail: gmrocker@dal.ca
} 
issues related to potential use of non-heart beating donors. In subsequent issues the Canadian Journal of Anesthesia will also publish manuscripts on cultural consideration in the diagnosis of brain death and on the contentious issue of mandatory reporting of "imminent" death to identify "potential" organ donors to third party organizations. None of these papers should be considered to represent the official view of the CCCS on the specific topic, but they have been offered for publication by their authors in the spirit of bringing some contentious issues to a wider audience to stimulate further discussion and debate.

Another collaborative initiative in organ and tissue donation should be highlighted. Responding to the CCCS request for discourse and collaboration around events leading to brain death, the Canadian Council for Donation and Transplantation sponsored a Canadian Forum on severe brain injury to neurological determination of death in Vancouver in April 2003. ${ }^{4}$ During the Forum, medical and non-medical specialists representing bioethics, health law, critical care, the emergency department, neuroscience communities, transplantation, palliative care, professional associations and colleges as well as Federal representation through Health Canada and the Canadian Institute of Health Information evaluated policies and practices concerning the management of critically injured patients with brain injury and/or poor neurological outcome. One purpose was to create and implement a Canadian definition of a neurological determination of death that can be applied consistently and reliably.

Why is there a need for a such an approach? The article by Doig and Burgess ${ }^{2}$ provides some stark evidence of the inconsistencies with which the current diagnosis of brain death is approached. One glaring example is the difference between the US and the UK. The US has adopted the concept of whole brain death. In the UK a diagnosis of brain death is based primarily on irreversible function of the brain stem. A report of the proceedings of the Canadian Forum on severe brain injury will be forthcoming shortly. Subsequent similar collaborations will be aimed at increasing awareness in Canada of other organ donation issues (e.g., use or non-use of non-heart beating donors) by involving the many disciplines that need to be part of processes aimed at clarifying key issues, whether legal or ethical, medical or procedural.

Change to policy or professional behaviour involves successful implementation of new strategies. Dissemination of new information is integral to this success. Collaboration with medical journals with wide readership can be a key part of that process. The CCCS is proud to be part of this process of collaboration. We are grateful to the Canadian Journal of Anesthesia for enabling the work of the CCCS to reach a wider audience with interests in critical care. We look forward to other initiatives that ultimately will be to the benefit of the patients and families we care for.

\section{Le don d'organes et de tissus à l'unité des soins intensifs : des efforts concertés}

En novembre 2002, un commentaire paru dans le Journal de l'Association médicale canadienne ${ }^{1}$ a attiré notre attention sur les questions reliées au don d'organes et de tissus à l'unité des soins intensifs. Dans le résumé présenté par la Société canadienne de soins intensifs (SCSI), qui a conduit à une déclaration de principe sur le don d'organes et de tissus [disponible sur le site web de la SCSI (www.canadiancriticalcare.org)], la SCSI fait appel à la collaboration d'autres groupes dans un esprit de compréhension et de respect mutuels. C'est réconfortant de voir de tels liens se former. Une des initiatives a été de créer des liens plus étroits entre la SCSI et le Journal canadien d'anesthésie. Le résultat apparait dans la publication, d'abord dans le présent numéro, d'une série d'articles écrits par les membres de la SCSI qui ont participé aux délibérations de notre groupe de travail sur le don d'organes et de tissus. L'article, intitulé Brain Death: resolving inconsistencies in the ethical declaration of death, correspond à l'examen personnel et professionnel de Doig et Burgess de l'évolution du concept de mort cérébrale depuis les premières discussions d'un comité de la Harvard Medical School, en 1968, jusqu'à aujourd'hui. ${ }^{2}$

Les raisons étaient nombreuses de créer un groupe de travail de la SCSI sur le don d'organes et de tissus, notre propre perception n'étant pas la moindre qu'en qualité de réanimateurs, nous ne sommes pas assez impliqués dans l'amélioration ou l'optimalisation du taux de donateurs d'organes et de tissus. Nous demeurons les médecins les plus susceptibles de participer aux soins prodigués aux donneurs d'organes potentiels à l'unité des soins intensifs (USI). De plus, les médecins de l'USI risquent d'être les plus concernés 
par toute stratégie introduite par les agences chargées d'améliorer le taux de donateurs d'organes et de tissus au Canada.

Parmi les stratégies possibles, il y a des changements à la législation pour permettre de fournir des renseignements, autrement restés confidentiels, sur des donneurs d'organes potentiels à des tiers. Il y a aussi de la possibilité d'un don d'organes de patients déclarés morts selon des critères cardiovasculaires, plutôt que l'habituel critère de mort cérébrale. Ces patients seraient des donneurs à cœur non battant. ${ }^{3}$ Cette façon de procéder est souvent utilisée aux Pays-Bas et dans quelques centres américains. Pour traiter de ces questions, et d'autres, nous avons réuni cinq personnes, non-médecins, et huit spécialistes de l'USI pour former un groupe de travail. Les non-médecins étaient : bioéthiciens (Kerry Bowman $\mathrm{PhD}$, University of Toronto, Alister Browne $\mathrm{PhD}$, Langara College, British Columbia), experts en droit de la santé (Jocelyn Downie SJD, Dalhousie University) et deux membres du public représentant la famille d'un donneur (Diane Craig, Ontario) et la famille d'un receveur d'organes (Lois Scott, New Brunswick). Les huit médecins de l'USI (Peter Dodek, Vancouver; Paul Boiteau, Chip Doig, Calgary ; Catherine Farrell, Montréal ; Giuseppe Pagliarello, Ottawa ; Graeme Rocker, Halifax (président), Sam Shemie, Toronto et Gordon Wood, Victoria) représentaient six provinces et des centres de soins tertiaires ayant des intérêts communautaires tant adultes que pédiatriques.

Une fois composée l'ébauche de la déclaration de principe, de nombreuses versions ont traduit la réflexion en cours et la construction du consensus. La version finale du résumé a été distribuée en août 2002. Dans cette déclaration, nous souhaitions, par exemple, un moratoire sur les programmes de donneurs à cœur non battant afin d'élargir la discussion et de débattre des questions éthiques soulevées par la situation. La SCSI s'est attirée quelques commentaires sur le conservatisme de sa position (ce qui ne nous a pas surpris), mais nous avons maintenu notre demande de nouvelle discussion. Pour cette raison, nous sommes heureux que le Journal canadien d'anesthésie ait accepté de publier prochainement un article sur les questions éthiques reliées à l'utilisation possible de donneurs à cour non battant. Dans les prochains numéros, le Journal va aussi publier des documents manuscrits sur l'élément culturel du diagnostic de mort cérébrale et sur la question controversée de la déclaration obligatoire de mort "imminente" qui permettrait de trouver des donneurs d'organes potentiels pour des organisations tierces. Aucun de ces articles ne prétend représenter la vision officielle de la SCSI sur le sujet en particulier, mais ils ont été présentés par leurs auteurs pour être publiés avec l'idée d'aborder certaines questions controversées auprès d'un auditoire plus large et de stimuler d'autres débats.

Une autre initiative de collaboration doit être soulignée. Répondant à la requête de la SCSI pour un dialogue et une collaboration sur les événements qui conduisent à la mort cérébrale, le Conseil canadien pour le don et la transplantation a parrainé en avril 2003 à Vancouver, ${ }^{4}$ un Forum canadien sur les lésions cérébrales graves menant à la détermination neurologique de la mort. Pendant le Forum, les spécialistes médicaux et non médicaux représentant la bioéthique, le droit de la santé, les soins intensifs, l'urgence, le milieu des sciences neurologiques, la transplantation, les soins palliatifs, les associations et collèges professionnels et le gouvernement fédéral, par Santé Canada et l'Institut canadien d'information sur la santé, ont évalué les politiques et les pratiques de traitement des patients gravement malades présentant des lésions cérébrales et/ou un mauvais pronostic neurologique. Un objectif était de formuler et d'utiliser une définition canadienne de la détermination neurologique de la mort, applicable de manière constante et fiable.

Pourquoi une telle approche est-elle nécessaire ? L'article de Doig et Burgess ${ }^{2}$ présente une preuve assez claire des incohérences qui président actuellement au diagnostic de mort cérébrale. Un exemple manifeste est la différence observée entre les États-Unis et le Royaume-Uni. Les Américains ont adopté le concept de coma dépassé. Au R-U, un diagnostic de mort cérébrale est principalement fondé sur l'irréversibilité de la fonction du tronc cérébrale. Un rapport sur les débats du Forum canadien sur les lésions cérébrales graves paraitra sous peu. D'autres collaborations similaires sont visées pour accroître, au Canada, la prise de conscience sur d'autres questions touchant le don d'organes (par ex., le recours, ou non, à des donneurs à cœur non battant) en intéressant de nombreuses disciplines à prendre part à la clarification des enjeux clés, légaux ou éthiques, médicaux ou techniques.

Modifier une politique ou un comportement professionnel comporte la mise en ouvre réussie de nouvelles stratégies. La diffusion de nouveaux renseignements est alors indispensable. La collaboration avec des journaux médicaux d'un vaste lectorat peut être une partie clé du processus. La SCSI est fière de faire partie de cette collaboration. Nous remercions le Journal canadien d'anesthésie d'avoir permis à la SCSI de présenter son travail à une plus large public intéressé à la réanimation. Nous attendons avec impatience d'autres initiatives qui bénéficieront, en définitive, aux patients et aux familles dont nous prenons soin. 


\section{References}

1 Rocker GM. Organ and tissue donation in the intensive care unit. CMAJ 2002; 167: 1248-9.

2 Doig CJ, Burgess E. Brain death: resolving inconsistencies in the ethical declaration of death. Can J Anesth 2003; 50: 725-31.

3 Campbell GM, Sutherland FR. Non-heart-beating organ donors as a source of kidneys for transplantation: a chart review. CMAJ 1999; 160: 1573-6.

4 Shemie SD, Doig C, Belitsky P. Advancing toward a modern death: the path from severe brain injury to neurological determination of death. CMAJ 2003; 168: 993-5. 